\title{
Article
}

\section{Le Sourire d'Albert Camus: actes du colloque d'Aix en Provence, 8-11 novembre 2017. Réunis et présentés par David H. Walker}

\author{
Orme, Mark Philip
}

Available at http://clok.uclan.ac.uk/25182/

Orme, Mark Philip ORCID: 0000-0003-0882-4744 (2018) Le Sourire d'Albert Camus: actes du colloque d'Aix en Provence, 8-11 novembre 2017. Réunis et présentés par David H. Walker. French Studies, 73 (1). pp. 141-142. ISSN 0016-1128

It is advisable to refer to the publisher's version if you intend to cite from the work. http://dx.doi.org/10.1093/fs/kny301

For more information about UCLan's research in this area go to http://www.uclan.ac.uk/researchgroups/ and search for <name of research Group>.

For information about Research generally at UCLan please go to http://www.uclan.ac.uk/research/

All outputs in CLoK are protected by Intellectual Property Rights law, including Copyright law. Copyright, IPR and Moral Rights for the works on this site are retained by the individual authors and/or other copyright owners. Terms and conditions for use of this material are defined in the policies page. 
Le Sourire d'Albert Camus: actes du colloque d'Aix en Provence, 8-11 novembre 2017. Réunis et présentés par David H. Walker. Columbia, SC: CreateSpace Independent Publishing, 2018. 279 pp., ill.

When, in the course of an interview in 1959, Jean-Claude Brisville asked Albert Camus if there was a theme in his work which had been neglected by critics, the writer responded by saying 'l'humour' (cited p. 8). The present volume, comprising eighteen contributions from international specialists following a recent conference on the topic in Aix-en-Provence, finally seeks to redress the balance. David $\mathrm{H}$. Walker sets the scene for the wide-ranging set of analyses when, in the Introduction to the collection, he notes that 'un sourire peut être moqueur, amer, amusé, narquois, affectueux, sceptique...' (p. 7). Indeed, the body of texts assembled here shines a light on the multifaceted nature of humour that pervades Camus's corpus; as Walker goes on to observe in his own contribution, there are more than sixty mentions of the word 'sourire' in La Peste alone (p. 20). The chapters are usefully organized into six categories: 'Considérations typologiques'; 'Le Monde, le moi et les autres'; 'Divertissements algériens'; 'Philosophie, politique, journalisme'; 'Rire et sourire: comédie ou tragédie?'; and 'Sourires et stylistique'. Together, these areas attract comprehensive coverage across the full range of Camus's work, from the early lyrical essays (where 'les sourires de la mer, du ciel ou du monde abondent', notes Agnès Spiquel, p. 75); his journalism (which Marie Bréjon examines through the prism of irony); theatre (in which 'le rire constitue une aide face au tragique', argues Virginie Lupo, p. 192); the imaginative writings, examined by several contributors; and even Camus's personal correspondence (where, observes Inés de Cassagne, 'le sourire, phénomène d'expression, [...] est un geste et un signe d'accueil', p. 104). A common theme across many of the contributions is what Barbara Eva Zauli calls 'la fonction épistémologique-éthique' of the Camusian smile (p. 51): a means by which to respond to the challenges of the human condition, characterized by the absurd. Irony plays a primary role here, as several contributors attest. Most notably, Giovanni Gaetani focuses on the overlooked L'Impromptu des philosophes, deemed 'le plus évident témoignage de l'ironie philosophique de Camus' (p. 141). Samara Geske examines the relationship between comedy and tragedy, a stance also adopted by Hélène Rufat in her evaluation of L'État de siège. Commenting on the author's political writings, Arnaud Dercelles and Rémi Baudouï argue that 'le rire chez Camus existe comme une sorte d'envers face à l'endroit de l'existence' (p. 164). The man behind the writing is also not neglected in the volume: Peter Dunwoodie examines the humour emanating from Camus's iconography, whereby 'nous sommes témoins d'un jeu' (p. 92) in the process of (re)presentation of identity. And, in an Appendix, the mystery of the so-called 'sourire Kruschen' (p. 273) - a reference to the 'sels Kruschen' mentioned in passing in La Mort heureuse and L'Étranger is intriguingly explored. In sum, this book is an important and welcome contribution to Camus studies, which examines a previously overlooked theme - even if, as Guy Basset astutely observes, 'c'est bien la vie quotidienne qui fait naître le rire' (p. 120).

\section{Mark Orme}

University of Central Lancashire 